\title{
Policy instruments for sustainable land management: the case of highland smallholders in Ethiopia
}

\author{
Bekele Shiferaw*, Stein T. Holden \\ Agricultural University of Norway, Department of Economics and Social Sciences, P.O. Box 5033, 1432 Ås, Norway
}

Received 3 March 1999; received in revised form 7 December 1999; accepted 29 December 1999

\begin{abstract}
Degradation of land continues to pose a threat to future food production potential in many developing economies. Various approaches, mainly based on command-and-control policies, have been tried (with limited success) in the past to encourage adoption of erosion-control practices by farm households. High transactions costs and negative distributional impacts on the welfare of the poor limit the usefulness of standards and taxes for soil and water conservation. One innovative approach is the use of interlinked contracts which create positive incentives for land conservation. This study analyses the social efficiency of such policies for erosion-control in the Ethiopian highlands using a non-separable farm household model. Incentive contracts linked with conservation seem to be promising approaches for sustainable resource use in poor rural economies. This may suggest that conservation programs should give greater consideration to better fine-tuning and mix of policies that help achieve both economic and environmental objectives. (C) 2000 Elsevier Science B.V. All rights reserved.
\end{abstract}

Keywords: Household models; Land degradation; Policy instruments; Peasant agriculture; Ethiopia

\section{Introduction}

The problem of land degradation and loss of food production potential in poor rural economies with fast growing populations has received increasing attention in recent years (Southgate, 1988; Anderson and Thampapilai, 1990; Scherr and Yadav, 1996). Soil and water conservation (SWC) has, therefore, become an area for public intervention. Lack of knowledge about appropriate instruments, however, hinders progress in implementing SWC programs in many developing

\footnotetext{
* Corresponding author. Tel.: +47-649-8600; fax: +47-649-48655.

E-mail address: bekele.shiferaw@ios.nlh.no (B. Shiferaw)
}

countries. Appropriate institutions and policy instruments that efficiently internalize land degradation externalities are urgently needed in many countries suffering from deterioration of their resource base.

In a world without transaction costs, farming practices and conservation investments undertaken by individual farmers also maximize the discounted value of social net returns in land use. Thus, government intervention, on efficiency grounds, is not needed. The necessary conditions for the social efficiency of private land use require that markets are perfectly competitive and that prices of all resources relevant for the well-being of all individuals reflect their social scarcity values. However, rural economies in LDCs are often far from being competitive, and 
face pervasive impediments (high transactions costs and imperfect information) and weak enabling conditions (incomplete property rights) (Hoff et al., 1993). Covariate risk also contributes to pervasive market imperfections. The divergence between private and social paths of soil use in LDCs may be attributed to imperfect information, high transactions costs, imperfect insurance and capital markets, incomplete property rights, and misguided government policies.

The interlinkages between poverty, population growth, and environmental degradation further complicate and reinforce the potential impact of market imperfections. Smallholders may, therefore, base their land use and investment decisions on distorted signals, which may prevent the resource use pattern from emulating the socially optimal path (McConnell, 1983; Shiferaw, 1997). Soil conservation investments that would increase social efficiency may, therefore, fail to be undertaken by individual users, and excessive degradation of land may ensue, as is reported in several case studies (e.g. FAO, 1986). However, from the efficiency perspective, the existence of market imperfections per se is not a sufficient condition for government intervention into market processes. The efficient level of land conservation that equates marginal social benefits and costs of abating degradation can result in a soil erosion level either lower or higher than the natural rate of regeneration. Thus, the mere existence of the land degradation externality does not necessitate policy intervention (Kirby and Blyth, 1987). The likelihood of a policy failure (inefficient intervention) and a net social welfare loss further strengthens this point. Hence, an economic efficiency justification for augmenting the 'invisible hand' mechanism with a 'visible hand' approach requires evaluation of social costs and benefits of interventions and demonstrating a possible net gain to society from implementing proposed interventions. Intervention in soil conservation is, therefore, justified when the net social benefit of intervention is shown to be positive.

Public policy instruments for sustainable land use include regulatory, economic, and advisory approaches (OECD, 1994). The economic incentives approach, based on voluntary behavior of resource users, is likely to be more successful than a coercive or regulatory approach (Chisholm, 1987; Panayotou,
1993). The non-point nature of the soil erosion externality and the high cost of monitoring individual levels of input use, make first-best policies difficult to implement. Thus, in countries like the US, soil conservation policy emphasizes an approach based on cooperative behavior in response to positive incentives (Reichelderfer and Kramer, 1993). In LDCs, regulatory standards and user charges on degrading inputs or soil loss are even more difficult to implement due to weak regulatory capability, scarcity of information, high transactions costs, and adverse distributional impacts on poor smallholders.

The purpose of this paper is to evaluate the role of various policy instruments for soil conservation and examine the rationale for public intervention into the market mechanism. Emphasis is given to incentive contracts, like cross-compliance and cost-sharing policies, which are also expected to offer positive distributional benefits to poor farmers. Moreover, the role of output pricing policies related to the erosivity of the crops is also examined. The rest of the paper is organized as follows. Section 2 presents the conceptual framework. A review of the agricultural sector and the land degradation problem in Ethiopia is presented in Section 3. Section 4 outlines the analytical methods. Results are discussed in Section 5. We summarize in the final section highlighting implications for conservation policy.

\section{Conceptual framework}

\subsection{The economic incentives approach to soil conservation}

Once the existence of a socially excessive level of land degradation is known, governments may resort to various policy instruments for mitigating or internalizing externalities. Some policy instruments specify quantity standards on the level of emission of the externality that cannot be exceeded by generators of that externality. These types of command-and-control regulations entail inflexible limits or technological requirements and stipulate a range of penalties for non-compliance. In contrast, the economic incentives approach utilizes market-based instruments designed to modify the behavior of the generators of the exter- 
nality through their effect on the prices of resource inputs used in economic activities. ${ }^{1}$

The economic incentives approach to soil conservation may use a range of policy instruments. Provision of secure land rights, price support and reduction of export taxes to less erosive crops, resource pricing, input taxes (subsidies), and credit subsidies are some examples (OECD, 1994). Secure land rights help extend the planning horizon of the poor and vest with the land user the benefits of investments in land improvement and conservation (Panayotou, 1993). Secure rights to land may serve as collateral and improve access to capital credit. Besides, macro-policies, like devaluation of overvalued exchange rates and interest rate adjustments, can be used. Interlinking program benefits with preferred land management practices is a useful approach particularly when the instrument itself (e.g. fertilizer subsidies) tends to substitute for resource conservation.

The effect of a general increase or decrease in commodity prices on soil and water conservation is unclear (LaFrance, 1992; Pagiola, 1996). It has been argued that depressing agricultural prices may reduce profitability of farming and discourage land-improving investments, whilst increasing commodity prices through its effect of raising farm returns may encourage cultivation of marginal lands (Southgate, 1988). It may also be argued that in the presence of a suitable land use policy and where rights to land are clearly defined, increased profitability of farming through higher prices may make conservation more attractive to the farmer. The impact of price changes on land management also depends whether the conserving input has beneficial or adverse impacts on yields (Shiferaw, 1997). Changes in relative prices, however, can have predictable impacts depending on the crops and inputs that are promoted or discouraged and the farmers' ability to respond to such price changes. A rise in the profitability of less erosive crops relative to more erosive crops can, for example, be expected to encourage soil-conserving land use and cropping pat-

\footnotetext{
1 We use the term economic incentives broadly as instruments designed to change the costs and benefits of an economic activity and thus stimulate (or deter) specific behavior (Sanders et al., 1999). The policy instrument may, however, also be understood as a mechanism used to modify the incentives faced by an economic agent to achieve certain environmental or other objectives.
}

terns, and conversely (Southgate, 1988; Panayotou, 1993).

The Pigouvian approach to internalizing externalities calls for taxes on degrading inputs and subsidies on conserving inputs in proportion to the marginal external damages or benefits resulting from the use of each input (Baumol and Oates, 1988). In the first best case, this requires information on the level of use of each type of input on each land type. Thus, governments prefer taxing the use of degrading inputs or subsidizing conserving inputs. When farmers have sufficient economic incentives to adopt soil-conserving practices on profitability grounds, the best policy is not provision of subsidies, rather removal of constraints that deter adoption. When significant off-site effects of soil erosion exist, conservation subsidies may be justified although on-site effects may be minimal.

The choice of policy instruments for resource conservation may depend on environmental effectiveness, costs of contracting, monitoring and enforcement, distributional effects, conformity with other policies and political preferences. The suitability of policy instruments may, therefore, be examined in relation to the ecological, economic and institutional setting (OECD, 1994). Owing to informational inadequacies and prohibitive costs of monitoring the activities of smallholders and enforcement of standards, the regulatory approach may, for example, have limited relevance for soil conservation policy. A mix of regulatory and economic incentives approaches may, however, prove to be useful (see Section 2.2). However, interlinked contracts may be inferior to general instruments like pricing policies in cases where administrative and enforcement costs are high. When local enforcement potential is large, cross-compliance policies may also be very effective. For example, past soil conservation programs in Ethiopia used a mix of coercive and incentives approaches. Farmers were forced to keep erosion-control methods once installed through food-for-work incentives. Enforcement was possible mainly due to strong local state power since peasant associations were entrusted with overseeing compliance.

However, designing a suitable subsidy scheme presents several incentive and targeting problems (Chisholm, 1987; Lutz et al., 1994). Production subsidies for inputs with significant external effects may artificially boost profitability of activities using these inputs and encourage resource depletion and degra- 
dation. Conservation subsidies may create perverse incentives to farmers to increase rates of soil erosion to qualify for subsidies or encourage planting on marginal lands made profitable through subsidies. Subsidies may also modify farmer behavior only as long as they continue to be paid. This implies that subsidies may have to be paid for maintenance as well. Therefore, a subsidy scheme should be designed carefully, and often entails a heavy strain on the economies of poor countries unless external assistance is made available.

\subsection{Cross-compliance approaches}

One mechanism to create economic incentives for conservation is based on interlinked compliance strategies that employ a mix of regulatory and incentives approaches based on voluntary behavior and positive economic incentives (Holden and Shanmugaratnam, 1995). Cross-compliance (interlinkage) means that conservation objectives are linked to access for a vital input (e.g. irrigation water) or access to certain farm program benefits is made contingent upon installing erosion-control practices on erodible lands.

Cross-compliance policies for resource conservation under peasant farming may offer some advantages. First, whilst direct subsidies for productive inputs may distort price signals and erode the incentive to economize scarce resources, subsidies linked to conservation can help mitigate the land degradation externality. Removal of input subsidies through adjustment programs and currency devaluation may also raise prices (e.g. fertilizer) and encourage soil mining and diminish household welfare. However, production subsidies linked to conservation can protect both the environment and the welfare of the poor. Subsidies for productive inputs linked to conservation can enable poor households to comply with conservation requirements without adverse impacts on their welfare, especially when the latter do not provide quick benefits. The increased production through such subsidies may boost national food security that may also benefit the urban poor and rural net buyers through lower prices. In food deficit countries, like Ethiopia, increased production can also contribute to self-sufficiency and reduce food imports. If improvements in efficiency, environmental quality, and equity can be achieved, such policies represent a win-win-win strategy. Second, where asymmetric information and transactions costs lead to market failures, despite differing distributional impacts, interlinked contracts may result in more efficient outcomes than could be achieved through isolated transactions (Bose, 1993; Hoff et al., 1993). When the regulating agency lacks full information on plot-specific erosion levels, on-site and off-site effects, and profitability of conservation technologies, interlinking of different markets may be second-best institutional innovations to achieve environmental targets through effective use of scarce information.

\section{Agriculture and land degradation in Ethiopia}

By all accounts, agriculture is the predominant sector of the economy. The sector is primarily dependent on smallholder farming. Smallholders cultivating fragmented micro-holdings produce more than $90 \%$ of the annual agricultural output. Despite its pivotal role, the performance of the sector has remained largely unsatisfactory. Food self-sufficiency remains to be an unattained objective. Between 1979 and 1980 and 1993 and 1994 food production grew by $0.5 \%$ per year while population grew by $3 \%$, implying a per capita food production decline of $2.5 \%$ (Zegeye and Habtewold, 1995). Another serious concern coupled with the stagnation of the sector has been the degradation of the resource base mainly due to soil erosion (FAO, 1986). The problem of degradation of the soil stock and loss of production potential is severe in the highlands that harbor 88 and $75 \%$ of the human and livestock populations, and constitute $95 \%$ of the cultivated lands. FAO (1986) estimates that $50 \%$ of the highlands are significantly eroded, of which $25 \%$ are seriously eroded, and $4 \%$ have reached a point of no return. Hence, soil erosion induced productivity decline is estimated to average $2.2 \%$ per annum from that of the 1985 level. Estimated annual rates of soil erosion on croplands at national level average 42 t/ha (Hurni, 1993). In a country with a fast growing population vulnerable to frequent famines, loss of food production potential is a concern not only for future generations but also for the present generation of Ethiopians.

The stagnation of the agricultural sector and degradation of the resource base can be attributed to several 
interrelated factors: misguided policies and neglect of the sector, technological stagnation, weak institutional support, insecure land rights, high population pressure, drought, political instability, and frequent wars (Shiferaw and Holden, 1997). Consistent with the general neglect of the agricultural sector in development theory, policy support to the sector prior to 1974 was very poor. Some of the reforms that followed the 1974 revolution, like 'land to the tiller', were later liquidated by misguided policies and ardent socialist orientation. Until the late 1980s, fertilizer and output marketing remained under state control while producers were forced to supply at prices fixed below the free market level. Credit supply, input distribution, output marketing, and extension were mainly targeted towards cooperatives and state farms which jointly accounted no more than $10 \%$ of the agricultural produce. Excessive surplus extraction and discriminatory policies discouraged private smallholder production and land-improving investments.

Coupled with disabling polices, the land reform of 1975 also failed to provide impetus to boost production and enhance sustainable land use. Although the reform policy enabled many landless farmers to gain access to land, the state ownership of land and the insecurity of usufruct rights hindered consummating the reform. Land still remains under state ownership while farmers only possess use rights. Land cannot be sold nor mortgaged. Moreover, rural infrastructure is poorly developed, agricultural research is rudimentary, and profitable production and conservation technologies are largely unavailable. Information on erosion-productivity relations or control measures is scanty and unavailable to farmers. Formal credit is available only for short-term loans for fertilizer, while long-term loans for investment (e.g. in land or livestock) are lacking.

We use data from our detailed survey of 120 farm households in Ada district, East Shewa zone in 1994/1995. The production system in the area is typical of the general mixed crop-livestock system in the highlands. Average production activities are reported in Table 1. Although soil erosion is a problem mainly on erodible uplands, proposed erosion control methods are not used. Less effective traditional practices like drainage furrows, waterways, and cut-off drains are used together with crop rotations where farmers perceive the threat of soil erosion. Short-term renting
Table 1

Smallholder production activities and estimated user costs of soil erosion in Ada district

\begin{tabular}{lccl}
\hline \multicolumn{4}{l}{ Crop production $(\text { kert })^{\mathrm{a}}$} \\
\hline Crops & Upland & Lowland & Total area \\
\hline Teff & 3.24 & 2.38 & 5.62 \\
Wheat & 0.51 & 0.43 & 0.94 \\
Barley & 0.16 & - & 0.16 \\
Pulses & 0.77 & 0.97 & 1.74 \\
Total & 4.67 & 3.78 & 8.46 \\
Estimated & \multicolumn{4}{l}{ marginal user costs } & (Birr per ton of eroded soil) \\
$\rho=0.54$ & 2.5 & 1.0 & \\
$\rho=0.20$ & 6.75 & 2.7 & \\
$\rho=0.10$ & 13.5 & 5.4 & \\
$\rho=0.05$ & 27.0 & 10.8 & \\
\hline
\end{tabular}

${ }^{a}$ Kert is the local unit of land measurement. The average from a sample of 20 plots measured during the survey indicates that a kert is about 0.3 ha.

${ }^{\mathrm{b}}$ Pulses include field peas, faba beans and lentils on uplands, and chickpeas and rough peas on lowland soils.

${ }^{\mathrm{c}}$ Birr is the Ethiopian currency. In 1994, US\$ $1 \cong 6$ Birr. The current rate is about 1 US\$ to 8 Birr.

of land is common although such practices often lack legal basis. Limited formal credit is available for fertilizer at a rate of $12 \%$, but informal rates may be as high as $100 \%$.

\section{Analytical methods}

Farm households' land use and conservation decisions are shaped by several factors: the policy environment, institutional arrangements, population pressure, asset endowments, household characteristics, access to new technologies, biophysical conditions, and opportunities for off-farm employment (Reardon and Vosti, 1992; Shiferaw and Holden, 1998, 1999). When consumption preferences and household characteristics condition production and investment decisions, a farm household approach is needed to study land use and investment decisions of smallholders.

This study develops a non-separable farm household model based on linear programming to investigate the role of alternative policy instruments for soil 
conserving land use. ${ }^{2}$ The model identifies a production plan which maximizes annual net returns defined as current net returns less the present value of future income loss caused by land productivity decline due to soil erosion (on-site user costs) subject to various farm-level resource supply and behavioral constraints. The condensed structure of the LP model is given in Table 2. The model includes crop production activities on two land types (upland and lowland) with three levels of fertilizer use, two technological options (improved and traditional varieties), and two land management options (with and without conservation) and livestock production, sale and consumption activities. Labor use activities (leisure, on-farm, off-farm, and hiring options) were defined seasonally, and activities for crop sale and consumption were included. The constraints included limits on 'owned' and rented land, labor (including leisure), oxen power, subsistence needs, animal feed requirements, restrictions on credit, crop rotations, and cash income.

Soil erosion levels for each production activity on two land types and two management options were estimated using the modified Universal Soil Loss Equation (USLE) adapted for Ethiopian conditions (Hurni, 1985). Actual measurements were used to generate values for the slope length and slope gradient factors. The effect of soil erosion on productivity was estimated econometrically based on time series data. ${ }^{3}$ The marginal user costs of soil (discounted perpetual productivity losses per unit of eroded soil) were assessed on levels of gross erosion from the two land types (see Table 1). The optimized value thus maximizes the returns to farming and non-farming activities less the user cost of current soil erosion. Activity budgets and resource supplies were specified for household groups with a pair of oxen, which better reflects average conditions in the area.

The cross-compliance policies analyzed include differing levels of input subsidies (for fertilizer, improved seeds, and a mix of fertilizer and improved seeds) of-

\footnotetext{
2 The mathematical set up of the model is available from the authors upon request. The full description of the model is given in Shiferaw (1997).

${ }^{3}$ The translog production function for teff (major crop) indicated a productivity decline of 45 and $20 \mathrm{~kg}$ per $\mathrm{cm}$ of soil depth lost on upland and lowland soils, respectively. At the ongoing rate of soil erosion, this amounts to 2.8 and $0.3 \%$ productivity decline per year (Shiferaw and Holden, 1999).
}

fered only when upland cereals are grown on land treated with conservation. When the incentive contract (linked to conservation) makes production on conserved land profitable, the household uses subsidized inputs and installs conservation structures on some of the land while traditional practices and unsubsidized inputs may continue to be used on the remaining land. The cost-sharing policies considered were differing subsidies per unit of labor used for installing conservation structures (soil-stone bunds) on erodible slopes. The incentive contracts were specified at varying levels per unit of labor used in conservation activities. The cost shares were computed as a share of the total discounted cost of construction and maintenance of structures. Since soil conservation is often undertaken during the slack period (January-May), labor costs are computed using the shadow value of labor during this period.

In addition to mitigating soil erosion, conservation structures may affect the yield path positively and/or negatively. For example, conservation may improve certain soil properties (e.g. improve water holding capacity) or raise relative returns to intensification (e.g. fertilizer use). It may also take $10-20 \%$ of the productive land out of production or increase pest incidence (e.g. rats and weeds) by providing a suitable habitat within the cropland. When initial yields with conservation are lower, a long time lag may be involved until conservation provides higher yields. The net effect of these additional positive and negative influences depends on the type of technology and local biophysical conditions. Since farmers in our surveys expressed both concerns, two stylized scenarios are developed to capture the differential effects of conservation: (a) short-term yields with conservation are $20 \%$ less (Case I) and (b) short-term yields with conservation are unaffected due to conservation (Case II). Therefore, subsidies are specified for cases where conservation does not offer immediate benefits to the smallholder. However, subsidies may still be needed even if yields are initially higher but not sufficient to cover the full cost of conservation. Our focus is, however, on evaluation of policies that may be used to increase adoption of existing conservation technologies, which do not seem to provide such short-term benefits.

The model was first solved using user costs estimated based on the farmers' average real rate of discount (discrete time) of 54\%. The latter was estimated 
Table 2

An aggregated structure of the non-separable farm household model

\begin{tabular}{|c|c|c|c|c|c|c|c|c|c|c|c|c|c|c|c|c|c|c|}
\hline & $\begin{array}{l}\text { Produce } \\
\text { crops }\end{array}$ & $\begin{array}{l}\text { Sell } \\
\text { crops }\end{array}$ & $\begin{array}{l}\text { Consume } \\
\text { crops }\end{array}$ & $\begin{array}{l}\text { Use } \\
\text { own } \\
\text { seed }\end{array}$ & $\begin{array}{l}\text { Buy } \\
\text { seed }\end{array}$ & $\begin{array}{l}\text { Buy } \\
\text { fertilizer/animal } \\
\text { feed }\end{array}$ & $\begin{array}{l}\text { Hire } \\
\text { in/out } \\
\text { land }\end{array}$ & $\begin{array}{l}\text { Soil } \\
\text { erosion }\end{array}$ & $\begin{array}{l}\text { Family } \\
\text { labor on } \\
\text { farm }\end{array}$ & $\begin{array}{l}\text { Family } \\
\text { labor } \\
\text { off-farm }\end{array}$ & $\begin{array}{l}\text { Labor } \\
\text { hiring }\end{array}$ & Leisure & $\begin{array}{l}\text { Keep breeding } \\
\text { stock and } \\
\text { oxen }\end{array}$ & $\begin{array}{l}\text { Sell } \\
\text { livestock }\end{array}$ & $\begin{array}{l}\text { Consume } \\
\text { livestock }\end{array}$ & Income & Relation & RHS \\
\hline Objective & $+\mathrm{C}$ & & & & $-\mathrm{C}$ & $-\mathrm{C}$ & $-1+\mathrm{C}$ & $-\mathrm{C}$ & & $+\mathrm{C}$ & $-\mathrm{C}$ & & $+/-\mathrm{C}$ & $+\mathrm{C}$ & & & & MAX \\
\hline Land & 1 & & & & & & $-/+1$ & & & & & & & & & & $\leq$ & B \\
\hline Soil erosion & $+\mathrm{A}$ & & & & & & & -1 & & & & & & & & & $=$ & 0 \\
\hline Income identity & $+\mathrm{C}$ & & & & $-\mathrm{C}$ & $-\mathrm{C}$ & $-1+\mathrm{C}$ & $-\mathrm{C}$ & & $+\mathrm{C}$ & $-\mathrm{C}$ & & $+1-\mathrm{C}$ & $+\mathrm{C}$ & & -1 & $=$ & $\mathrm{F}$ \\
\hline Labor on-farm & $+\mathrm{A}$ & & & & & & & & -1 & & -1 & & $+\mathrm{A}$ & & & & $=$ & 0 \\
\hline Family labor supply & & & & & & & & & 1 & 1 & & 1 & & & & & $\leq$ & B \\
\hline Leisure demand & & & & & & & & & & & & 1 & & & & $-\beta$ & $\geq$ & B \\
\hline Oxen power & $+\mathrm{A}$ & & & & & & & & & & & & $-\mathrm{A}$ & & & & $\leq$ & 0 \\
\hline Fertilizer & $+\mathrm{A}$ & & & & & -1 & & & & & & & & & & & $=$ & 0 \\
\hline Seed use & $+\mathrm{A}$ & & & $-\mathrm{A}$ & $-\mathrm{A}$ & & & & & & & & & & & & $\leq$ & 0 \\
\hline Production & $-\mathrm{A}$ & $+\mathrm{A}$ & $+\mathrm{A}$ & $+\mathrm{A}$ & & & & & & & & & & & & & $\leq$ & 0 \\
\hline Consumption & & & $+\mathrm{A}$ & & & & & & & & & & & & $+\mathrm{A}$ & $-\beta$ & $\geq$ & B \\
\hline Cash income & & $+\mathrm{A}$ & & & & & & & & & & & & $+\mathrm{A}$ & & & $\geq$ & B \\
\hline Credit constraint & & & & & & $+\mathrm{A}$ & & & & $+\mathrm{A}$ & & & & & & & $\leq$ & B \\
\hline Rotations & $+/-1$ & & & & & & & & & & & & & & & & $\leq$ & 0 \\
\hline Crop residue & $-\mathrm{A}$ & & & & & -1 & & & & & & & $+\mathrm{A}$ & & & & $\geq$ & 0 \\
\hline
\end{tabular}

The C, A, B, F and $\beta$ 's, respectively, represent, sets of objective function coefficients, input-output coefficients, available resource supplies or requirements, farm fixed costs, and the marginal propensity to consume estimated from a system of Engel equations. Allocation of labor and oxen power was specified over seven periods in a year. 
based on hypothetical questions to elicit the present value equivalent of a future income stream. For alternative policies, the model thus determines the level of soil erosion and conservation investments endogenously using the farmers' estimated rate of discount, thereby enabling comparative efficiency analysis of the instruments for sustainable land management. This was done by computing the net present value of soil productivity loss prevented over the lifetime of conservation practices when the economic incentive is provided less the flow of any real social costs of conservation as given in Eq. (1).

$$
\begin{aligned}
& \sum_{t=1}^{T}\left(\lambda\left(E_{t}^{i}-E_{t}^{w i}\right)-\left[\theta(1-\gamma)\left(I_{t}+M_{t}\right)\right.\right. \\
& \left.\left.\quad+S_{t}+A_{t}\right]\right)(1+\rho)^{-t+1}
\end{aligned}
$$

Where, $E_{t}^{i}$ and $E_{t}^{w i}$ are, respectively, soil erosion levels with and without the incentive contract, $I_{t}$ is the labor requirement for installing conservation structures (hence $\left.I_{t>1}=0\right), M_{t}$ is the annual labor requirement for maintenance of structures $\left(M_{t=1}=0\right), S_{t}$ is the cost of the subsidy in year $t, A_{t}$ is annual administrative costs (assumed $10 \%$ of the subsidy cost), $\lambda$ is the marginal user cost of soil erosion with the social rate of discount, $\theta$ is the shadow value of family labor, $\gamma$ is the cost-share covered by the incentive contract (for the cost-sharing policy only), and $\rho$ is the social rate of discount. The payment required in subsequent years $\left(S_{t>1}\right)$ to create an incentive for the farmer to maintain structures once built through the starting economic incentive $\left(S_{t=1}\right)$ was estimated by computing the income level that would equalize the flow of net benefits with conservation to that without conservation as given by:

$S_{t}=\pi_{t}^{\mathrm{c}}-\pi_{t}^{\mathrm{nc}}$ for all $t>1$

Where $\pi_{t}^{\mathrm{c}}$ and $\pi_{t}^{\mathrm{nc}}$ are farm profits with and without conservation, respectively. This was estimated for the major cereal (teff) grown in the area as:

$$
\begin{aligned}
S_{t}= & p_{t}\left[f_{t}^{\mathrm{c}}\left(x_{i t}^{\mathrm{c}}\right)-f_{t}^{\mathrm{nc}}\left(x_{i t}^{\mathrm{nc}}\right)\right] \\
& -\sum_{i=1}^{n} e_{i t}\left(x_{i t}^{\mathrm{c}}-x_{i t}^{\mathrm{nc}}\right) \text { for all } t>1
\end{aligned}
$$

Where $f^{\mathrm{c}}(\cdot)$ and $f^{\mathrm{nc}}(\cdot)$ are the per hectare production functions under the two regimes, $x_{i t}$ is the use of input $i, p_{t}$ is the output price, and $e_{i t}$ the input price. The difference in the cost of production between the two land management systems is mainly the cost of conservation. Since subsistence-constrained households often face problems in deferring current consumption (Holden et al., 1998), the incentive contract is needed until the discounted net benefits of switching onto the soil-conserving practice are positive $\left(\pi_{t}^{\mathrm{c}}>\right.$ $\left.\pi_{t}^{\mathrm{nc}}\right)$. When conservation reduces yields by $20 \%$, it takes up to 11 years until net benefits of conservation are positive. If all the subsidy needed from Year 2 is paid in that year, the discounted value of the subsidy (at $r=0.54$ ) is estimated at Birr $430 \mathrm{ha}^{-1}$ of conserved land. The benefit-cost evaluation was done at differing social rates of discount $(\rho=0.05,0.1,0.2)$ for $T=15$ years. The policy instrument is considered to improve social welfare when Eq. (1) is positive or the benefit-cost ratio is sufficiently greater than one. Finally, the effect of changing the relative prices of erosive and non-erosive crops on land use and conservation decisions was examined through a $20 \%$ decrease (increase) of the price of an erosive crop (teff) or less erosive crops (pulses), respectively.

\section{Results and discussion}

\subsection{Effect of cross-compliance policies}

The effect of cross-compliance policies for fertilizer and improved seed inputs on land use and conservation investments is presented in Table 3 . When conservation reduces immediate benefits by $20 \%$, no conservation of erodible lands occurs until about $50 \%$ of the $(1993 / 1994)$ price of fertilizer is covered through the subsidy. Even at $50 \%$ subsidy, only some $20 \%$ of upland cereals ( $17 \%$ of the uplands) are grown on conserved land. The increase in the level of the subsidy to 75 and $90 \%$, respectively, raises adoption of conservation to 45 and $62 \%$ of the upland area. ${ }^{4}$ The benefit-cost ratios (BCR) for $50-90 \%$ fertilizer subsidies show that, considering the on-site effects of soil erosion alone over the 15-year period, the

\footnotetext{
${ }^{4}$ The corresponding ratio of the upland area conserved is different from the cereal area conserved since fertilizer is only used for cereals (teff, wheat, and barley) and at present local improved varieties of pulses are unavailable.
} 
Table 3

Efficiency of fertilizer and improved seed contracts linked to conservation

\begin{tabular}{|c|c|c|c|c|c|c|c|c|c|c|c|}
\hline & \multicolumn{5}{|c|}{ Conservation $20 \%$ less productive } & \multicolumn{6}{|c|}{ Conservation equally productive } \\
\hline & \multicolumn{3}{|c|}{ Fertilizer subsidy (\%) } & \multicolumn{2}{|c|}{ Seed subsidy $(\%)$} & \multicolumn{3}{|c|}{ Fertilizer subsidy (\%) } & \multicolumn{3}{|c|}{ Seed subsidy (\%) } \\
\hline & 50 & 75 & 90 & 90 & 100 & 10 & 25 & 50 & 10 & 25 & 50 \\
\hline Net income (Birr) & 4408 & 4590 & 4718 & 5278 & 5289 & 4432 & 4598 & 4937 & 5285 & 5309 & 5436 \\
\hline Area conserved (kert) & 0.80 & 2.15 & 2.91 & 0.53 & 0.55 & 0.96 & 3.89 & 4.07 & 0.57 & 1.76 & 3.33 \\
\hline Upland conserved (\%) & 16.5 & 45 & 62 & 11.6 & 11.9 & 19.5 & 84 & 85.8 & 11.9 & 38.8 & 66.0 \\
\hline \multicolumn{12}{|l|}{ Upland cereal area } \\
\hline Conserved $(\%)$ & 20.0 & 52.8 & 71.6 & 13.3 & 13.7 & 23.6 & 100 & 100 & 14.4 & 49.9 & 79.0 \\
\hline Soil loss (t/ha) & 33.8 & 29.3 & 25.7 & 36.4 & 36.2 & 31.5 & 20.9 & 19.8 & 35.4 & 29.4 & 25.5 \\
\hline Total damage & & & & & & & & & & & \\
\hline prevented $^{\mathrm{a}}$ (Birr) & 172 & 583 & 914 & 211 & 227 & 382 & 1352 & 1460 & 177 & 726 & 1085 \\
\hline Cost of the subsidy & 130 & 449 & 622 & 90 & 95 & 7 & 77 & 196.1 & 3 & 23 & 81 \\
\hline $\begin{array}{l}\text { Own installation and } \\
\text { maintenance costs }\end{array}$ & 92 & 246 & 332 & 61 & 63 & 182 & 743 & 776 & 110 & 336 & 635 \\
\hline Conservation costs & 235 & 741 & 1017 & 160 & 167 & 190 & 828 & 991 & 113 & 361 & 724 \\
\hline Average costs & 293 & 343 & 350 & 299 & 304 & 199 & 212 & 243 & 196 & 205 & 217 \\
\hline \multicolumn{12}{|l|}{ Benefit/cost ${ }^{\mathrm{b}}$} \\
\hline$\rho=0.05$ & 1.77 & 1.92 & 2.19 & 3.19 & 3.28 & 4.36 & 3.58 & 3.30 & 3.41 & 4.39 & 3.30 \\
\hline$\rho=0.1$ & 0.73 & 0.79 & 0.90 & 1.32 & 1.36 & 2.01 & 1.63 & 1.47 & 1.57 & 2.01 & 1.50 \\
\hline$\rho=0.2$ & 0.27 & 0.29 & 0.33 & 0.49 & 0.50 & 0.86 & 0.69 & 0.60 & 0.68 & 0.86 & 0.63 \\
\hline
\end{tabular}

${ }^{a}$ The present value of annual yield losses prevented due to the policy instrument over the life time of conservation structures (15 years) discounted over perpetuity. For estimated marginal user costs under different rates of discount see Table 1.

${ }^{\mathrm{b}}$ Total damages prevented/cost of conservation. The reported benefits and costs are only for $\rho=0.1$. For $\rho \neq 0.1$, only the final results are reported.

instrument will not increase net social benefits unless the social rate of discount is close to $5 \%$. At the rate of discount of $\rho \geq 0.1$, the policy instrument is also unlikely to be socially profitable, even if one assumes that structures may form terraces and have a longer lifetime. Only an increase in the user costs of soil or a lowering of the social rate of discount could make the instrument a Pareto improvement. Since switching into a conserving practice lowers immediate income, it requires more than $90 \%$ subsidy before the instrument could have a significant impact on land use and investment behavior. The soil loss declines progressively from $35.6 \mathrm{t} / \mathrm{ha}$ without the subsidy to $25.7 \mathrm{t} / \mathrm{ha}$ with $90 \%$ subsidy, respectively. Since the linked fertilizer subsidy relaxes the credit constraint, the returns to the policy instrument increase with the level of the subsidy. But, more conservation also brings higher subsidy costs from the second year and hence makes social profitability difficult to attain.

When short-term yields are $20 \%$ less with conservation, an improved seed (30\% higher yielding compared to traditional cultivars) subsidy for cereals is, however, socially profitable even at $\rho=0.1$ (Table 3 ). When technical change allows a $30 \%$ increase in yields, a shift onto the soil-conserving practice still allows a $10 \%$ increase in yields over traditional cultivars thereby allowing adoption of conservation practices without severe impacts on meeting subsistence needs. Moreover, compared to the fertilizer subsidy, the seed subsidy has a lower average cost per area conserved. Thus, although it requires up to $90 \%$ subsidy to induce some conservation, at $\rho \leq 0.1$, both 90 and $100 \%$ seed subsides are socially efficient. In this case, a subsidy for improved seeds linked with conservation that sufficiently counteracts the yield-depressing effects of structures and induces conservation at lower cost is likely to be socially more attractive than a high cost fertilizer subsidy. However, even with the $100 \%$ seed subsidy, the level of conservation achieved in the short-term is very low. Soil loss only decreased from $38.7 \mathrm{t} /$ ha without the seed subsidy to $36.2 \mathrm{t} /$ ha with the $100 \%$ subsidy.

When yields are unchanged due to conservation, even a $10 \%$ fertilizer subsidy enables $24 \%$ of upland 
cereals to be grown with conservation. An increase in the level of the fertilizer subsidy to $25 \%$, brings all the upland cereals ( $84 \%$ of the upland area) into conservation farming. A further increase in the level of the fertilizer subsidy to $50 \%$ encourages slightly more conservation and cropping of cereals on uplands (86\% conserved). Further increase in the level of the subsidy does not spur much conservation as land hiring and rotational constraints begin to be binding. Besides, the higher demand for conservation labor and the parallel increase in opportunity cost of labor as the level of the subsidy increases, reduce the marginal conservation effect of the policy instrument. However, the 10-50\% fertilizer subsidies are socially efficient at $\rho=0.1$. Soil erosion progressively declined from $35.6 \mathrm{t} / \mathrm{ha}$ without the economic incentive to 20 t/ha with the $50 \%$ fertilizer subsidy.

With a yield-neutral conservation, the improved seed subsidy will also have a comparable level of social efficiency as the fertilizer subsidy. Again this is related to the lower cost of the seed subsidy per unit of land conserved. A policy that plans to transform all cereals on uplands to conservation farming is also socially efficient at $\rho \leq 0.1$. However, the net benefits increase initially, reach a maximum between 10 and $50 \%$ levels, and start to fall thereafter. Like the fertilizer subsidy, the fall in BCR is related to the effect of cropping patterns on resulting levels of erosion, and a rise in the opportunity cost of labor in farming with the increase in the subsidy. This is observed in the form of a larger decrease in the soil erosion level from 10 to $25 \%$ subsidy compared to higher levels of the subsidy. This implies that although the area under conservation increases with the subsidy, after some level, the marginal change in soil erosion falls as erosive crops come to be grown on treated land. The policy instrument decreased soil erosion successively from $37.3 \mathrm{t} /$ ha without the policy to $22.2 \mathrm{t} / \mathrm{ha}$ with the $75 \%$ seed subsidy.

The effect of a mix of fertilizer and seed subsidies is presented in Table 4. For the case of yield-decreasing conservation, a $50 \%$ seed subsidy was combined with differing levels of fertilizer subsidies. Although the $50 \%$ seed subsidy alone brought no conservation, mixing it with a fertilizer subsidy of 25,50 and $75 \%$, respectively, raised the upland cereal area conserved to 13.5, 99 and $100 \%$. The first two combinations are efficient at $\rho \leq 0.1$, but the 50-50 scheme was only marginally so. If soil conservation is a preferred social goal, a policy that enables growing of upland cereals with conservation, is socially efficient at $\rho \leq 0.1$. The rise in the profitability of farming following the increase in the subsidy raises the opportunity cost of labor used for conservation. This, coupled with growing of erosive crops on conserved land introduces decreasing returns to the subsidy. The policy instrument progressively reduced soil erosion from $38.7 \mathrm{t} / \mathrm{ha}$ without the instrument to 21 t/ha with the 50-75 seed-fertilizer subsidy.

For the case of yield-neutral conservation, a 10\% fertilizer subsidy was combined with differing levels of seed subsidies. Table 3 shows that a $10 \%$ improved seed subsidy led to the adoption of conservation technology on $12 \%$ of uplands. Adding a $10 \%$ fertilizer subsidy raises adoption to about $14 \%$ of the upland area operated. Similarly, adding a $10 \%$ fertilizer subsidy over the 25 and $50 \%$ seed subsidy raises adoption, respectively, from 39 and $66 \%$ to 67 and $80 \%$ of the cultivated upland area. Thus, a 50\% seed subsidy is almost equivalent to a mix of a $10 \%$ fertilizer subsidy with $25 \%$ seed subsidy. This implies that, depending on the availability of the economic incentive and the budget constraint, the fertilizer and seed contracts can be combined in different proportions without a loss in their efficiency. At $\rho \leq 0.1$, the mix of seed and fertilizer subsidies is also socially efficient. Conservation can be extended to $80 \%$ of the uplands without loss of efficiency. The BCR of the instrument seems to be increasing first and decreasing later mainly due to the differences in the erosivity of cereals and a rise in the shadow value of labor. The instrument seems to achieve highest efficiency between the 10-10 and 50-10 mix of seed-fertilizer subsidies. The incentive system reduced soil erosion successively from $37.3 \mathrm{t} / \mathrm{ha}$ without the subsidies to $23 \mathrm{t} / \mathrm{ha}$ at the $50-10$ seed-fertilizer subsidy.

\subsection{Effect of cost-sharing (labor subsidies)}

Analytical results for the cost-sharing contract are also given in Table 4. When conservation is yield-depressing, none of the uplands would be conserved if the initial payment is less than 4 Birr/laborday $(\mathrm{B} / \mathrm{L})$. This amounts to $120 \%$ of the total discounted cost of construction and maintenance of structures. 
Table 4

Efficiency of cost-sharing and a mix of improved seed and fertilizer contracts linked to conservation

\begin{tabular}{|c|c|c|c|c|c|c|c|c|c|c|c|c|}
\hline & \multicolumn{6}{|c|}{$\begin{array}{l}\text { Conservation } 20 \% \text { less } \\
\text { productive (I) }\end{array}$} & \multicolumn{6}{|c|}{$\begin{array}{l}\text { Conservation equally } \\
\text { productive (II) }\end{array}$} \\
\hline & \multicolumn{3}{|c|}{$\begin{array}{l}\text { Seed and fertilizer } \\
\text { subsidy }(\%)\end{array}$} & \multicolumn{3}{|c|}{$\begin{array}{l}\text { Labor subsidy } \\
\text { (Birr/manday) }\end{array}$} & \multicolumn{3}{|c|}{$\begin{array}{l}\text { Seed and fertilizer } \\
\text { subsidy }(\%)\end{array}$} & \multicolumn{3}{|c|}{$\begin{array}{l}\text { Labor subsidy } \\
\text { (Birr/manday) }\end{array}$} \\
\hline & $50-25$ & $50-50$ & $50-75$ & 4 & 7 & 9 & $10-10$ & $25-10$ & $50-10$ & 1 & 2 & 3 \\
\hline Net income (Birr) & 5274 & 5350 & 5645 & 5253 & 5285 & 5338 & 5306 & 5382 & 5557 & 5260 & 5277 & 5356 \\
\hline Area conserved (kert) & 0.54 & 4.11 & 4.34 & 0.28 & 0.84 & 1.47 & 0.63 & 3.34 & 4.11 & 0.58 & 2.64 & 4.58 \\
\hline$\%$ upland conserved & 11.7 & 84.3 & 86.7 & 6 & 17.2 & 30.3 & 13.7 & 66.6 & 80.4 & 12.7 & 57.7 & 100 \\
\hline $\begin{array}{l}\text { Upland cereal area } \\
\text { conserved }(\%)\end{array}$ & 13.5 & 99.2 & 100 & 6.9 & 20.7 & 36.2 & 17.1 & 79.2 & 100 & 14.7 & 69.7 & 113 \\
\hline Soil loss (t/ha) & 37.2 & 21.7 & 21.1 & 37 & 35 & 32.5 & 35.3 & 25.3 & 23 & 35.2 & 24.7 & 18.2 \\
\hline $\begin{array}{l}\text { Total damages } \\
\text { prevented (Birr) }\end{array}$ & 206 & 1570 & 1614 & 82 & 296 & 565 & 181 & 1103 & 1316 & 249 & 1211 & 1814 \\
\hline Cost of subsidy & 91 & 717 & 948 & 75 & 315 & 660 & 8 & 70 & 138 & 21 & 191 & 497 \\
\hline $\begin{array}{l}\text { Own installation and } \\
\text { maintenance costs }\end{array}$ & 103 & 783 & 827 & 0 & 0 & 0 & 145 & 763 & 940 & 90 & 312 & 375 \\
\hline Conservation costs & 204 & 1572 & 1870 & 83 & 346 & 726 & 154 & 837 & 1091 & 113 & 522 & 922 \\
\hline Average costs & 376 & 382 & 430 & 295 & 414 & 494 & 243 & 251 & 266 & 194 & 198 & 235 \\
\hline Benefit/costs & & & & & & & & & & & & \\
\hline$\rho=0.05$ & 2.39 & 2.35 & 2.06 & 2.57 & 2.23 & 2.03 & 2.55 & 2.88 & 2.66 & 4.77 & 5.03 & 4.28 \\
\hline$\rho=0.1$ & 1.01 & 1.00 & 0.86 & 0.99 & 0.86 & 0.78 & 1.17 & 1.32 & 1.21 & 2.21 & 2.32 & 1.97 \\
\hline$\rho=0.2$ & 0.38 & 0.38 & 0.32 & 0.33 & 0.29 & 0.26 & 0.50 & 0.56 & 0.50 & 0.95 & 1.00 & 0.84 \\
\hline
\end{tabular}


Thus, the cost-sharing policy fails to induce conservation unless the contract covers more than the entire investment cost. This is because investing labor in conservation becomes unprofitable unless the incentive payment is large enough to compensate for the lower initial yields. Increase in the labor subsidy to 7 and $9 \mathrm{~B} / \mathrm{L}$ raised adoption of the soil-conserving technology to 17 and $30 \%$ of the upland area, respectively. Soil erosion decreased progressively from $38 \mathrm{t} / \mathrm{ha}$ without the contract to $32 \mathrm{t} / \mathrm{ha}$ with $9 \mathrm{~B} / \mathrm{L}$ ( $280 \%$ incentive payments). Although the area conserved increases with the incentive payment, the scheme is inefficient and efficiency falls as the public 'cost-sharing' increases.

However, with a yield-neutral conservation, even a $1 \mathrm{~B} / \mathrm{L}$ subsidy (20\% cost-sharing) could propel some conservation. Raising the labor subsidy to $3 \mathrm{~B} / \mathrm{L}$ (60\% cost-sharing) brings all uplands under conservation farming. Under the current situation where improved seeds are unavailable for all upland crops and fertilizer is used only on a few crops, the cost-sharing (labor subsidy) policy may, therefore, be an effective means of achieving a wider adoption of conservation structures. All levels of the labor subsidy are efficient at $\rho \leq 0.1$. Soil erosion declined successively from $38 \mathrm{t} /$ ha without the subsidy to about $18 \mathrm{t} / \mathrm{ha}$ with a $60 \%$ cost-sharing. The most efficient level of cost-sharing seems to be reached between 20 and $60 \%$.

\subsection{Effect of pricing policies}

\subsubsection{Taxing the price of an erosive crop (teff)}

The incentive effect of depressing the price of an erosive but a major cash and staple crop (teff) by $20 \%$, relative to other crops, is given in Table 5. In response to the relative price change, smallholders adjust their land use and cropping patterns. The area under teff is more than halved while the area under wheat is more than doubled, and the area of pulses increases by about $60 \%$. Household income falls by up to $12 \%$ as a result. When the farmer begins to incorporate the user costs of current soil erosion into decision-making, teff ceases to be grown on erodible lands. Even when user costs are unaccounted for (in the basic model), soil loss decreases by $12 \%$ ( $5 \mathrm{t} / \mathrm{ha})$ although bunds have not been installed on the uplands. Similarly, soil erosion decreases by $16 \%$ without adoption of bunds when user costs are accounted at high rates of discount $(r=0.54)$. As more weight is given to future productivity loss, reduction in teff area alone is insufficient to mitigate erosion and adoption of conservation structures becomes necessary.

Table 5

Effect of a $20 \%$ tax on the price of an erosive crop (teff) on resource use and conservation decisions (\% of the before price change)

\begin{tabular}{|c|c|c|c|c|c|c|}
\hline \multirow[t]{2}{*}{ Issues considered } & \multirow{2}{*}{$\begin{array}{l}\begin{array}{l}\text { Basic model } \\
\text { (without user costs) }\end{array} \\
\text { I and } \text { II }^{\mathrm{a}}\end{array}$} & \multirow{2}{*}{$\begin{array}{l}\text { User costs accounted } \\
(r=0.54) \\
\text { I and II }\end{array}$} & \multicolumn{2}{|c|}{$\begin{array}{l}\text { User costs accounted } \\
(r=0.1)\end{array}$} & \multicolumn{2}{|c|}{$\begin{array}{l}\text { User costs accounted } \\
(r=0.05)\end{array}$} \\
\hline & & & I & II & I & II \\
\hline Net income & 89.2 & 89.1 & 88.7 & 88.3 & 88 & 88.3 \\
\hline Teff (kert) & 53.3 & 42.9 & 44.2 & 43.6 & 68.4 & 53.7 \\
\hline Wheat & 266.9 & 291.0 & 254.6 & 265.2 & 153.5 & 221.5 \\
\hline Barley & 45.0 & 43.2 & 60.1 & 59.6 & 85.0 & 60.6 \\
\hline Pulses & 167.9 & 176.7 & 203.4 & 77.5 & 128.1 & 153.8 \\
\hline Teff area upland & 26.9 & 0.0 & 0.0 & 0.0 & 0.0 & 0.0 \\
\hline$\%$ upland conserved & $0.0(0)$ & $0.0(0)$ & $0.0(0)$ & $86.7(39)$ & $56.4(22)$ & $100.0(100)$ \\
\hline Soil loss (t/ha) & $88.5(33.7)$ & $84.1(31.8)$ & $87.8(31.6)$ & $96.5(25.4)$ & $104.1(28)$ & $87.7(15.7)$ \\
\hline Family labor supply (mandays) & 103 & 103 & 100 & 114 & 93 & 110 \\
\hline Labor off- farm & 150 & 144 & 139 & 98 & 191 & 107 \\
\hline Leisure & 83 & 83 & 81 & 81 & 77 & 80 \\
\hline Hired labor & 76 & 64 & 75 & 39 & 0.0 & 64 \\
\hline Teff marketed surplus & 19 & 0.0 & 0.0 & 0.0 & 47 & 23 \\
\hline Wheat marketed surplus & 501 & 513 & 373 & 406 & 174 & 305 \\
\hline
\end{tabular}

${ }^{\mathrm{a}}$ The scenarios analyzed are: $\mathrm{I}=$ Short-term yields with conservation are $20 \%$ less than conventional farming, $\mathrm{II}=$ Short-term yields with conservation are equal to conventional farming, and $r=$ the household's real rate of discount used in computing the user costs. Values given in parentheses refer to actual values after the price change. 
Table 6

Effect of a $20 \%$ price support for less erosive crops (pulses) on resource use and conservation decisions (\% of the before price change) ${ }^{\mathrm{a}}$

\begin{tabular}{|c|c|c|c|c|c|c|}
\hline \multirow[t]{2}{*}{ Issues considered } & \multirow{2}{*}{$\begin{array}{l}\text { Basic model } \\
\text { (without user costs) } \\
\text { I and II }\end{array}$} & \multirow{2}{*}{$\begin{array}{l}\text { User costs accounted } \\
(r=0.54) \\
\text { I and II }\end{array}$} & \multicolumn{2}{|c|}{$\begin{array}{l}\text { User costs accounted } \\
(r=0.1)\end{array}$} & \multicolumn{2}{|c|}{$\begin{array}{l}\text { User costs accounted } \\
(r=0.0 .05)\end{array}$} \\
\hline & & & I & II & $\bar{I}$ & II \\
\hline Net income (Birr) & 102.1 & 102.2 & 101.7 & 101.6 & 102.0 & 101.7 \\
\hline Teff (kert) & 92.6 & 92.7 & 100.1 & 98.9 & 97.6 & 100.4 \\
\hline Wheat & 133.1 & 131.9 & 98.7 & 103.5 & 105.0 & 98.7 \\
\hline Barley & 77.5 & 74.9 & 102.0 & 99.0 & 95.0 & 100.0 \\
\hline Pulses & 113.2 & 119.5 & 100.2 & 109.0 & 100.5 & 100.6 \\
\hline Teff area upland & 88.4 & 88.3 & 107.2 & 105.0 & 88.8 & 101.1 \\
\hline$\%$ upland conserved & $0.0(0)$ & $0.00(0)$ & $0.00(0)$ & $119(53)$ & $94.9(37)$ & $100.0(100)$ \\
\hline Soil loss (t/ha) & $98.2(37.4)$ & $98.6(37.4)$ & $100.6(36.2)$ & $95.4(25)$ & $99.3(26.7)$ & $100.6(18)$ \\
\hline Family labor supply (mandays) & 98 & 98 & 98 & 98 & 98 & 98 \\
\hline Labor off- farm & 93 & 93 & 99 & 100 & 98 & 100 \\
\hline Leisure & 103 & 103 & 103 & 103 & 103 & 102 \\
\hline Hired labor & 105 & 105 & 114 & 126 & 106 & 101 \\
\hline Teff marketed surplus & 81 & 84 & 98 & 95 & 94 & 100 \\
\hline Wheat marketed surplus & 175 & 164 & 97 & 105 & 106 & 97 \\
\hline
\end{tabular}

${ }^{\text {a }}$ For additional descriptions, see the note under Table 5.

However, the change in cropping patterns resulting from the price policy allows sizable reductions in soil erosion without much soil conservation effort.

The fall in income reduced the consumption of leisure and teff by up to 23 and $14 \%$, respectively. Since wheat is not a substitute for teff and due to the fall in income, the consumption of wheat also decreases by up to $10 \%$. The price policy also prompts households to be only self-sufficient in teff. Thus, wheat largely substitutes for the decline in the marketed output of teff. Although this partial analysis does not reveal the general equilibrium effects, the policy is likely to have substantial impacts on the marketing of teff and wheat. The decrease in marketed surplus of teff may have an eventual effect of driving up teff prices. The increased supply of wheat may also depress its own price. In our model, prices are exogenous and such second-round effects cannot be traced. Future research should investigate such effects in a multi-market or general equilibrium framework.

\subsubsection{Supporting the price of less-erosive crops (pulses)}

Table 6 presents, the incentive effect of supporting the relative price of less-erosive crops (horse beans, field peas, lentils, chick peas, and rough peas) by $20 \%$. Pulses together account for about $20 \%$ of the cropped area. Despite the very low yields, farmers do not use fertilizer on these crops. Pulses are often used for replenishing soil nutrients and they precede cereals in the rotation cycle. They are also mainly produced for own consumption. Thus, the responsiveness to the prices of these crops is likely to be limited. The results also indicate that, unlike the case of the teff price-tax policy, the relative increase in the profitability of pulses does not decrease the area under teff to bring a significant reduction in soil erosion. Teff planted on erodible slopes did not also show a significant decline. The area under wheat also remains about half of that under an equivalent tax on the price of teff. The pulse area also increased only marginally or remained the same. As a result, the desired effect of the price policy to stimulate soil-conserving land use and cropping pattern did not succeed. Hence, the soil erosion level remained comparable to that before the price change. Since household income showed only a slight increase, the effect on consumption was limited. Marketed surplus of teff declined by up to $20 \%$ in the basic model, but this effect disappears when user costs are considered. The overall outcome of the pulse price-support policy does not differ much from the case without the policy. The low relative prices of pulses and their low current yields limit the effectiveness of the policy. ${ }^{5}$

\footnotetext{
5 The 1993/1994 average yields ( $\mathrm{kg} / \mathrm{kert}$ ) of teff and pulses were 280 and 200, while average prices (Birr $/ \mathrm{kg}$ ) were 2.38 and 1.60 , respectively.
} 
Under the current low productivity of pulses, a much larger pulse price support is required before significant changes in cropping patterns occur to have any notable effect on soil erosion. Thus, the pulse price-support policy did not bring a comparable change in household behavior as the teff price-tax policy.

\section{Summary and policy implications}

The problem of land degradation and productivity decline in countries with fast growing populations that are also suffering from poverty and malnutrition is becoming an important area for government intervention. From the viewpoint of economic efficiency alone, the mere existence of land degradation does not, however, necessitate public intervention. An economic rationale for public intervention prevails when market failures leading to socially excessive land degradation exist. Market failures, when they exist, may affect market signals and encourage socially sub-optimal land use and investment patterns. This study analyzes some policy instruments to mitigate the soil erosion externality using empirical data from Ethiopia.

Table 7

The effect of cross-compliance policies (incentive contracts linked to conservation) on soil conservation decisions as compared to subsidies unlinked to conservation

\begin{tabular}{|c|c|c|c|c|}
\hline \multirow[t]{2}{*}{ Subsidies (\%) } & \multicolumn{2}{|l|}{ Unlinked subsidy } & \multicolumn{2}{|l|}{ Linked subsidy } \\
\hline & Upland conserved (\%) & Soil loss (t/ha) & Upland conserved (\%) & Soil loss (t/ha) \\
\hline \multicolumn{5}{|c|}{ Fertilizer subsidy $\mathrm{I}^{\mathrm{a}}$} \\
\hline 0 & 0.0 & 35.6 & 0.0 & 35.6 \\
\hline 25 & 0.0 & 39.4 & 0.0 & 35.6 \\
\hline 50 & 0.0 & 37.9 & 16.6 & 33.8 \\
\hline 75 & 0.0 & 38.0 & 45.0 & 29.3 \\
\hline 90 & 0.0 & 37.2 & 62.0 & 25.7 \\
\hline \multicolumn{5}{|c|}{ Fertilizer subsidy II $^{\mathrm{b}}$} \\
\hline 0 & 0.0 & 35.6 & 0.0 & 35.6 \\
\hline 10 & 0.0 & 38.7 & 19.5 & 31.5 \\
\hline 25 & 0.0 & 39.3 & 84.0 & 20.9 \\
\hline 50 & 0.0 & 38.0 & 85.8 & 19.8 \\
\hline \multicolumn{5}{|l|}{ Seed subsidy I } \\
\hline 0 & 0.0 & 38.7 & 0.0 & 38.7 \\
\hline 90 & 0.0 & 41.5 & 11.6 & 36.4 \\
\hline 100 & 0.0 & 41.5 & 11.9 & 36.2 \\
\hline \multicolumn{5}{|c|}{ Seed subsidy II } \\
\hline 0 & 6.5 & 37.3 & 6.5 & 37.3 \\
\hline 10 & 5.5 & 36.6 & 11.9 & 35.4 \\
\hline 25 & 3.4 & 36.6 & 38.8 & 29.4 \\
\hline 50 & 0.0 & 39.5 & 66.0 & 25.5 \\
\hline 75 & 0.0 & 42.4 & 83.8 & 22.2 \\
\hline \multicolumn{5}{|c|}{ Seed-fertilizer subsidy I } \\
\hline $50-25$ & 0.0 & 39.6 & 11.7 & 36.5 \\
\hline $50-50$ & 0.0 & 36.0 & 84.3 & 21.7 \\
\hline $50-75$ & 0.0 & 36.1 & 86.7 & 21.1 \\
\hline \multicolumn{5}{|c|}{ Seed-fertilizer subsidy II } \\
\hline $10-10$ & 2.8 & 36.7 & 13.7 & 35.3 \\
\hline $25-10$ & 0.5 & 37.4 & 66.6 & 25.3 \\
\hline $50-10$ & 0.0 & 42.5 & 80.4 & 23.0 \\
\hline
\end{tabular}

${ }^{a} \mathrm{I}=$ Short-term yields with conservation are $20 \%$ less than conventional farming.

${ }^{\mathrm{b}} \mathrm{II}=$ Short-term yields with conservation are equal to conventional farming. 
The results show that policies that link production subsidies with soil conservation can provide opportunities for countering erosion-induced productivity declines without adverse impacts on marketed surplus of food and the welfare of the poor. Such policies may, therefore, represent improvements in efficiency, equity, and environmental quality. However, if conservation technologies significantly reduce short-term household income, fertilizer subsidies linked to conservation failed to be efficient unless the social rate of discount is less than $10 \%$. Seed subsidies and a mix of seed and fertilizer subsidies were, however, more efficient since they enable sizable reductions in erosion damage at low cost. If the social rate of discount is as high as $20 \%$, such economic incentives also become socially inefficient. When conservation leaves short-term benefits unchanged, cross-compliance policies for fertilizer, and a mix of seed and fertilizer subsidies linked with conservation were able to create sufficient incentives for sustainable land management and reduce erosion-induced productivity loss efficiently. The social returns to these policies, however, disappear as the rate of discount rises above $10 \%$. Compared to unlinked subsidies, the cross-compliance approach was more effective to counter the soil erosion externality. When unlinked input subsidies are provided, the enhanced profitability of farming discourages the need to conserve the soil stock and thus conservation disappears as the subsidy increases (see Table 7).

Furthermore, at low rates of discount, the costsharing (labor subsidy) policy was not efficient when conservation decreases short-term yields. The cost-sharing policy was, however, more efficient when conservation is yield-neutral in the short-term. This indicates that utilizing household labor through incentive contracts, like food-for-work programs, may be an effective approach for soil conservation. This approach, also widely used in conservation programs, is likely to be effective when used to subsidize the smallholder until conservation provides positive net benefits over traditional land use. Such contracts may, however, be very costly unless they are made available through external assistance.

The efficiency of the policy instruments depends on the user cost of soil erosion, the social rate of discount, and the lifetime and productivity effects of conservation structures. An increase in the user cost, a decrease in the rate of discount, and an increase in the life of structures improve the efficiency of the policy instrument. The user costs depend on the productivity impact of soil erosion, output prices, and the social rate of discount. A decrease in soil depth and technical change raise the productivity impact of soil erosion. Increase in prices and a decrease in the discount rates also raise the user costs. Moreover, taxing the most erosive crop (teff) is more effective in abating soil erosion than supporting the prices of less erosive crops (pulses). The limited success of the latter approach was mainly due to low initial prices and low productivity of pulses. Areas for future research include empirical estimation of transaction costs associated with various policy instruments and how such costs may influence policy recommendations, exploring alternative institutional arrangements that may help reduce transactions costs, investigating how poverty may influence farmers' responsiveness to incentive contracts, and careful estimation of the user costs by land type and land use, preferably using a dynamic bio-economic household model.

\section{Acknowledgements}

The Norwegian Universities' Committee for Development Research and Education (NUFU) and the Norwegian Research Council kindly provided funds for this research. We also thank the Soil Conservation Research Project (SCRP) for sponsoring the fieldwork in Ethiopia and providing us some of the data used in this study. The International Livestock Research Institute (ILRI) also provided some logistical support at the final stages of this work.

\section{References}

Anderson, J.R., Thampapilai, J., 1990. Soil conservation in developing countries: project and policy intervention. Policy and Research Series 8, The World Bank, Washington, D.C.

Baumol, W.J., Oates, W.E., 1988. The Theory of Environmental Policy. Cambridge University Press, Cambridge.

Bose, G., 1993. Interlinked contracts and moral hazard in investment. J. Develop. Econ. 41, 247-273.

Chisholm, A., 1987. Abatement of land degradation: regulations vs. economic incentives. In: Chisholm, A., Dumsday, R. (Eds.), Land Degradation: Policies and Problems. Cambridge University Press, Cambridge, pp. 223-247. 
Kirby, M., Blyth, M., 1987. An economic perspective on government intervention in land degradation. In: Chisholm, A., Dumsday, R. (Eds.), Land Degradation: Policies and Problems. Cambridge University Press, Cambridge, pp. 213-222.

FAO, 1986. Highlands reclamation study-Ethiopia. Final Report, Vols. 1 and 2. Food and Agricultural Organization of the United Nations, Rome.

Hoff, K., Braverman, A., Stiglitz, J.E. (Eds.) 1993. The Economics of Rural Organization. Oxford University Press, Oxford.

Holden, S., Shanmugaratnam, N., 1995. Structural adjustment, production subsidies and sustainable land use. Forum for Development Studies 2, 247-266.

Holden, S.T., Shiferaw, B., Wik, M., 1998. Poverty, credit constraints and time preferences: of relevance for environmental policy? Environ. Develop. Econ. 3, 105-130.

Hurni, H., 1985. Soil conservation manual for Ethiopia. A field guide for conservation implementation. Soil Conservation Research Project, Addis Ababa.

Hurni, H., 1993. Land degradation, famines and resource scenarios in Ethiopia. In: Pimental, D. (Ed.), World Soil Erosion and Conservation. Cambridge University Press, Cambridge.

LaFrance, J.T., 1992. Do increased commodity prices lead to more or less soil degradation? Austr. J. Agric. Econ. 36 (1), 57-82.

Lutz, E., Pagiola, S., Reiche, C., 1994. The cost benefits of soil conservation: the farmers' viewpoint. The World Bank Research Observer 9 (2), 273-295.

McConnell, K., 1983. An economic model of soil conservation. Am. J. Agric. Econ. 65 (1), 83-89.

OECD, 1994. Public policies for the protection of soil resources. OECD Environment Monographs No. 89. Organization for Economic Co-operation and Development, Paris.

Panayotou, T., 1993. Economic instruments for natural resource management in developing countries. FAO Economic and Social Development Paper 121, 206-265.

Pagiola, S., 1996. Price policy and returns to soil conservation in semi-arid Kenya. Environ. Resou. Econ. 8, 251-271.
Reardon, T., Vosti, S.A., 1992. Issues in the analysis of the effects of policy on conservation and productivity at the household level in developing countries. Quart. J. Int. Agric. 31 (4), 380 396.

Reichelderfer, K., Kramer R.A., 1993. Agricultural resource policy. In: Carlson, G.A., Zilberman, D., Miranowski, J.A. (Eds.), Agricultural and Environmental Economics. Oxford University Press, Oxford, pp. 441-490.

Sanders, D.W., Huzar, P.C., Sombatpanit, S., Enters, T. (Eds.), 1999. Incentives in Soil Conservation: From Theory to Practice. Oxford and IBH Publishing.

Scherr, S.J., Yadav, S., 1996. Land degradation in the developing world: Implications for food, agriculture, and the environment to 2020. Disc. Paper 14. IFPRI, Washington, D.C.

Shiferaw, B., 1997. Peasant Agriculture and Sustainable Land Use in Ethiopia: economic analyses of constraints and incentives for soil conservation. Ph.D. Thesis, Agricultural University of Norway.

Shiferaw, B., Holden, S.T., 1997. Peasant agriculture and land degradation in Ethiopia: reflections on constraints and incentives for soil conservation and food security. Forum for Development Studies 2, 277-306.

Shiferaw, B., Holden, S.T., 1998. Resource degradation and adoption of land conservation technologies in the Ethiopian highlands: a case study in Andit Tid, North Shewa. Agric. Econ. 18 (3), 233-248.

Shiferaw, B., Holden, S.T., 1999. Soil erosion and smallholders' conservation decisions in the Ethiopian Highlands. World Develop. 24 (4), 739-752.

Southgate, D., 1988. The economics of land degradation. Environment Department Working Paper No.2, The World Bank, Washington D.C.

Zegeye, T., Habtewold, D., 1995. Food Security and Situation Analysis. In: Demeke, M., Amha, W., Ehui, S., Zegeye, T. (Eds.), Food Security Nutrition and Poverty Alleviation in Ethiopia. Addis Ababa Ethiopia. 